Ballas, D., Dorling, D. and Hennig, B.D. (2017) Analysing the regional geography of poverty, austerity and inequality in Europe: a human cartographic perspective, Regional Studies, forthcoming - Colour On-line APPENDIX maps at the very end of this submitted version.

\title{
Analysing the regional geography of poverty, austerity and inequality in Europe: a human cartographic perspective
}

\author{
Dimitris Ballas, Danny Dorling and Benjamin Hennig
}

\begin{abstract}
This paper presents a human cartographic approach to the analysis of the impact of austerity and the economic crisis across Europe's regions. First, the paper reflects on past insights and debates on the analysis and mapping of poverty and wealth and of the effects of austerity in particular. It then presents and discusses a wide range of cartograms and maps (including the subjects of unemployment and poverty as well as related themes such as educational attainment and migration). These images highlight social and spatial inequalities and also illustrate that the most severe social divides within Europe are more often within states rather than between them. To that end the paper also argues the case for a co-ordination of urban, regional, national and European policies and EU spending to ameliorate the impacts of austerity and to enhance social and territorial cohesion. Finally, the paper highlights the increasingly important role of geographers and of the field of Regional Studies in so many recent debates about the future of the European project and of the possibility of a Europe of cities and regions rather than a Europe of nation-states.
\end{abstract}

\section{INTRODUCTION}

Europe is currently suffering a deep political and economic crisis following years of turmoil and austerity measures that have disproportionately and brutally hit the most disadvantaged regions and citizens across most of the continent. At the same time, there has been a revival of nationalisms and divisions in this part of the world that, a decade ago, seemed to be united in diversity and moving towards ever-closer union. Concentrated poverty near to riches and profound spatial inequality have long been persistent features of all European countries, with inequalities often being most stark within the most affluent cities and regions, such as London. In other parts of Europe levels of inequality and poverty have been reducing and are often much lower. However, the severe economic crisis and austerity measures have led, in many cases, to an enhancement of existing disparities. 
There is a long and successful history of theoretical and empirical work in the field of Regional Studies aimed at analysing social and spatial disparities in Europe. This paper aims to build on this work and to offer new insights into the analysis of austerity in Europe with the use of innovative geovisualisations that can be used to present more information in more useful ways than has been possible before and which enhance more subtle understanding of key issues. The work presented here draws on and builds on recent and on-going relevant work (BALLAS, DORLING and HenNig, 2014 and 2017; HenNig, BALlas and Dorling, 2015), which considers and visualises Europe and its economy, culture, history and human and physical geography in terms of a single large land mass. In particular, this paper uses images created for a social atlas of Europe using state of the art Geographical Information Systems (GIS) and new cartography techniques in order to offer an alternative way of visualising the continent and its people in a more fluid way, in many cases plotting aspects of the lives of Europeans without imposing artificial national boundaries on those patterns.

We use a human cartographic approach to illustrate the impact of austerity and the economic crisis across Europe's regions, highlighting particular areas and types of regions. First, the paper reflects on past insights and debates on the analysis and mapping of poverty and wealth and of recent austerities in particular. It then presents and discusses examples of human cartograms highlighting social and spatial inequalities and also illustrating that the real social divides within Europe are more often within states rather than between them. Finally, the paper highlights the increasingly important role of geographers and of the field of Regional Studies in the debates about the future of the European project. The paper is accompanied by an 
online appendix of colour versions of the human cartograms presented here, as well as additional such maps which could not be included in this paper.

\section{REGIONAL STUDIES OF POVERTY AND WEALTH}

There is a long tradition of regional studies of poverty and wealth and of uneven development between cities and regions at various levels and in different contexts. These studies can be distinguished between efforts to provide an evidence base and highlight spatial disparities in income and wealth as well as studies that focus on geographical divisions of labour and capital, and studies that attempt to theorise, analyse and understand the mechanisms that lead to social and spatial inequalities. Such inequalities can be viewed either as a process or as an outcome of a process. As Doreen Massey put it, in her seminal paper 'In What Sense a Regional Problem?' published in this journal when the current authors were all children:

The word [inequality] tends to get used indiscriminately in the literature in two rather different ways. First, there is inequality in the degree of attractiveness of a particular area to the dominant form of economic activity; secondly, there is inequality in terms of various indicators of social well-being (rate of unemployment, per capita income, degree of external control of production, for example). The two are evidently not necessarily the same. In a crude sense, one is a cause and the other an effect.

(MASSEY, 1979: 234)

Examples of studies that explore causes and mechanisms include the above work (and much follow up work, such as MASSEY, 1995), as well as the seminal work of Gunnar Myrdal on cumulative causation (MYRDAL, 1957). There has been further and significant progress to that direction over the years (e.g. see AMIN and THRIFT, 1992; Hudson, 2007; Dicken, 2011; Dorling, 2015; Krugman, 1991; Fujita et al, 1999; Harvey, 2011; Martin 2011; McCAnN and ShepPard, 2003; PeCK, 1996; Pike et al, 2007). There has also been a considerable amount of relevant work focusing on 
the current post-2007 crisis (HADJIMIHALIS, 2011; HADJIMIHALIS and HUDSON, 2014; MARTIN, 2011; RAE, 2011; SMITH, 2013).

For instance, HADJIMIHALIS (2011) highlighted the significant role and contribution of what he describes as neoliberal urban and regional development discourses in the context of the economic and financial crisis in Europe to the downplaying of socio-spatial justice issues. RAE (2011) focused on the impact of the crisis upon the Central and Eastern European countries that became part of the EU as part of its 2004 and 2007 enlargement and argued that their peripheral status within the EU made them vulnerable to the financial crisis and helped to further enhance the historical East-West divide in Europe. However, he also pointed out that the EU membership status of these countries resulted in them benefiting from the introduction of counter-measures that have partly offset these disparities. Another example of a relevant study is the work of SMITH (2012), who highlighted the geo-political and geo-economic manifestations of the crisis across Europe's inter-dependent regions and beyond.

It is interesting to note that one of the key arguments made in relation to the causes and impacts of the crisis is that the creation of the euro was not based on criteria that are thought to be pre-requisites for a successful monetary union, which include 'a degree of economic and productive similarity' between countries and regions, 'high rates of geographical mobility, not only for capital but also for labour', 'similar propensities to inflation' and an automatic fiscal mechanism that through a centrally organised tax and benefit system compensates for different national and regional shocks and growth rates (HADJIMIHALIS and HUDSON, 2014: 211; MARTIN, 2001). Also of relevance here is the work of MIDELFART et al (2003) who considered the degree to which the economic geography of Europe may matter for the success of 
the euro as well as what the possible impacts of the adoption of the euro upon the economic geography of the continent, including how it may affect the location of different economic activities, social and spatial inequalities and population mobility.

It is also important to recognise the long tradition of regional studies of poverty and wealth aimed at measurement and analysis of key indicators. Amongst the key proponents of such work was Peter Townsend, whose seminal book entitled Poverty in the United Kingdom (1979) provided a theoretical and conceptual basis for the estimation and mapping of deprivation, poverty and social exclusion and for subsequent relevant studies (e.g. see TOWNSEND, 1987; CARSTAIRS, 1995; SMITH et al., 2015), including extensions that aimed at measuring both poverty and wealth (DorLing et al., 2007). There has also been considerable work aimed at providing estimates of income, wealth and other related socio-economic indicators at regional and local levels using a wide range of methods including statistical approaches (BRAMLEY and SMART, 1996; HAMNETT, 1997) and labour market accounts (BAILEY and TUROK, 2000). There are also many examples of regional studies that present and use evidence to map and analyse the impact of the current post-2007 crisis (e.g. see KITSON et al., 2011).

Another important aspect that relates to the second type of studies described above is that of mapping and visualisation. Again, there has been considerable progress in the development of mapping methods for the visualisation of social structure and social and spatial inequalities across cities and regions (e.g. DoRLING, 1995 and 2012; Dorling and Thomas, 2016; Hennig and Calzada, 2015).

However, despite some exceptions, most of the regional studies of poverty and wealth tend to focus on geographical data and patterns within countries and regions rather than exploring potential inter-regional linkages and patterns between regions 
from different countries. Amongst the notable exceptions has been the work of organisations such as the European Commission (EuropeAn COMMISSION, 2015) that aimed at systematically considering all regions of the European Union (EU) in one set of analysis and mapping (also see ANNONI and DIJKSTRA, 2013). The remainder of this paper builds on this work by using new geovisualisation methods to highlight regional disparities in Europe, while at the same time engaging with issues raised in relevant theoretical and empirical studies such as those briefly reviewed above.

\section{A HUMAN CARTOGRAPHIC APPROACH TO MAPPING A EUROPE OF REGIONS}

...we must re-create the European family in a regional structure, called, it may be, the United States of Europe

(Winston Churchill, 19 September 1946 The Churchill Society, 1946; our emphasis)

It may sound inconceivable today (and especially given the 2016 UK referendum result on the membership of the EU) that a statement such as the above could be made by a British Prime Minister and even more so by the leader of the Conservative Party. Yet, this is an extract from a speech delivered by Winston Churchill in Zurich calling for a more united Europe. The idea of a Europe of Regions and of a European People instead of a Europe of nation-states has long been at the heart of the thinking and efforts that have gradually led to the creation of the EU. Nevertheless, the recent ascendancy of extremist and populist groups (e.g. see DoXIADIS and MATSAGANIS, 2013; FIESCHI, 2016; ZONDEROP, 2013) has contributed to a painting of a picture of Europe where Euroscepticism is becoming a dominant trend and where the revival of old nationalisms and divisions is, apparently, inevitable. The 2016 Brexit referendum 
result in the United Kingdom further enhances this picture and adds strength to such a view. In addition, the nationalist populist trends seem to be more dominant in countries that were most badly hit by the 2008 financial crisis and austerity measures and especially where the political scapegoating of the EU has been most prevalent (HALKiOpoulou and VAsilopoulou, 2014) and where the social safety net protecting the most vulnerable is weakest (HALKIOPOULOU and VLANDAS, 2016).

Growing social divisions following austerity is also the case in Britain, where the massive austerity measures imposed by domestic political parties since 2010 had a devastating impact ${ }^{1}$ upon the most disadvantaged people and regions, while at the same time there have been attempts to put the blame on immigration rather than the systematic underfunding of public services and the increasing tolerance of unaffordable housing and poverty (DoRLING, 2016). However, despite this climate, there is still evidence of widespread expressions of feelings of solidarity and common European transnational belonging across the continent (FRIEDMAN and THIEL, 2016), including from within the United Kingdom and even after the Brexit referendum result there have been reports for a surge of support for the EU in big European countries (ROSE, 2016) as well as many very recent manifestations of support for the EU within Britain such as the \#marchforeurope events in September 2016 (STONE, 2016).

In this paper we engage with the idea of a Europe of Regions from a human cartographic and human geography perspective, with a focus on regional inequalities in poverty and wealth. The work presented here has many antecedents, but draws especially on an ongoing mapping project of European countries, cities and regions (BAllas, Dorling and Hennig, 2014 and 2017) which aims to highlight the notion

\footnotetext{
${ }^{1}$ movingly illustrated in the film I, Daniel Blake, winner of the Cannes Palme d'Or 2016 top filmmaking prize.
} 
of Europe as a single entity by looking at its physical and population geography simultaneously in new ways, using up-to-date statistics, state of the art GIS and novel human cartography techniques.

People are used to conventional maps of their regions and countries. Conventional maps appear on television and especially in weather reports showing geographical regions as they appear from space. However, looking at a city, region or country from space is not the best way to see its human geography. Often details within urban areas with large populations (but small area size) are virtually invisible to the viewer. It has long been argued, admittedly initially by a relatively small group of scholars, that there is a need for human-scaled visualisations to address these issues (Dorling and Fairbairn, 1997; Dorling, 2007; Dorling and ThOMAS, 2004; BALlas and Dorling, 2011; HenNig, 2013).

The mapping approach adopted here involves the redrawing of geographical regions on the basis that the area of each should be proportional to the number of people who live in each small neighbourhood, rather than land mass. Such maps are known as cartograms (TOBLER, 2004) and it can be argued that they are also part of recent trends in geography that see a revival and further advancement of spatial analysis and visualisation techniques in the set of methods used in the discipline (TURNER, 2006). This kind of visualisation differs from traditional maps and rebalances the emphasis on treating all experiences as equally important, rather than greatly highlighting what occurs in the most sparsely populated rural regions (RITTSCHOF et al., 1996). In particular, the cartographic technique we used applies the density-equalising approach proposed by two physicists, Michael Gastner and Mark Newman. Using the diffusion of gas analogy in physics, these two physicists 
developed a cartogram approach that moved the borders of territories with the 'flow' of people, until density is equal everywhere (GASTNER and NEWMAN, 2004).

The population cartogram technique is a more appropriate way to visualise geographical data in the social sciences if you are interested in mapping people rather than land, especially if you do not wish to concentrate on over-emphasizing empty land in the map image. What the technique does is to iteratively alter the original map so that areas of high density expand and areas of low density shrink in such a way that eventually all areas are of, say, equal population density. This method has been used extensively for the mapping of countries using state-level data (DoRLING, 2006; DORLING et al., 2008), but as yet there are relatively limited applications for mapping at regional and sub-regional levels.

The maps presented in this paper are created with a method that takes the approach outlined above a step further and is more suitable for the mapping of cities and regions across an entire continent. In particular, the maps were created using the gridded-population cartogram approach (see HENNIG, 2013). Its creation builds on the same density-equalising approach described above, but it is implemented in order to create a gridded-population cartogram, meaning that the underlying projection onto which the map has been transformed is one where people are equally distributed on a grid stretched so that each grid cell has an area proportional to the population within that cell. In particular, this involves dividing the whole territory to be mapped into a grid of cells of equal size and estimating the population distribution accordingly. The next step is to apply the density equalizing method to resize each cell proportionally to the number of people living within it. This process results in a contiguous griddedpopulation cartogram, meaning that each new grid cell has an area proportional to the number of people that live there, but still touches only its original eight neighbouring 
cells. The edges of each cell become curved lines The size of each of the grid cells therefore reflects the number of people living in this area; the projection means that the base map itself reflects the real population distribution on a coherent geographical reference (and not the population based on artificial administrative units like nation states). Figure 1 illustrates how the method works with a hypothetical example of four areas (HeNNig, 2015). The sizes of the areas (and borders) are changed until the space between the people in each area is the same everywhere (and therefore the population density in all areas is the same). The cartogram is created by 'diffusing' the people resulting in a final visualization with an even spatial spread of population. As people diffuse, borders are moved with them until all spatial units have equal population density.
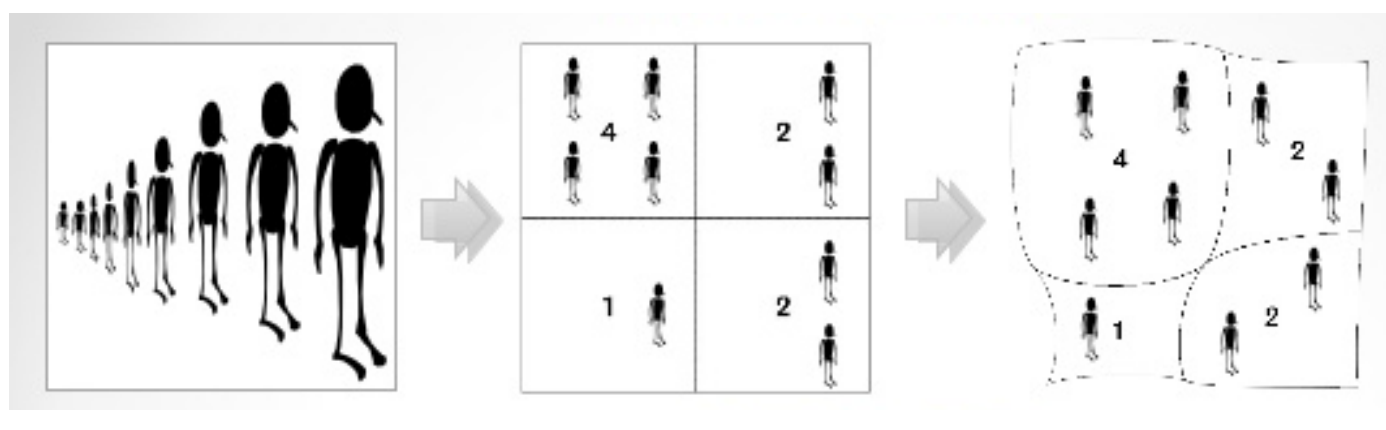

Figure 1: An illustration of the Gastner and Newman diffusion-based method for producing density-equalizing gridded population cartograms (after Hennig, 2013).

As noted above, the approach we adopt aims to highlight the notion of Europe as a single entity by looking at its physical and population geography simultaneously in new ways. To that end we have included all states that (at the time of creating the cartograms presented in this paper) have demonstrated a commitment to a common European future by being closely associated with the EU, either as current members or as official candidate states (or official potential candidates for EU accession) and/or 
states which are signed up to any of the following agreements: European Economic Area, the Schengen Zone, the European Monetary Union. Figure 2 shows a gridded population cartogram of these European countries using a greyscale shading scheme (see online appendix for a rainbow colour scheme version of this map) denoting the year of association with the EU and also signposting some of the major city regions (with the capital cities underlined).

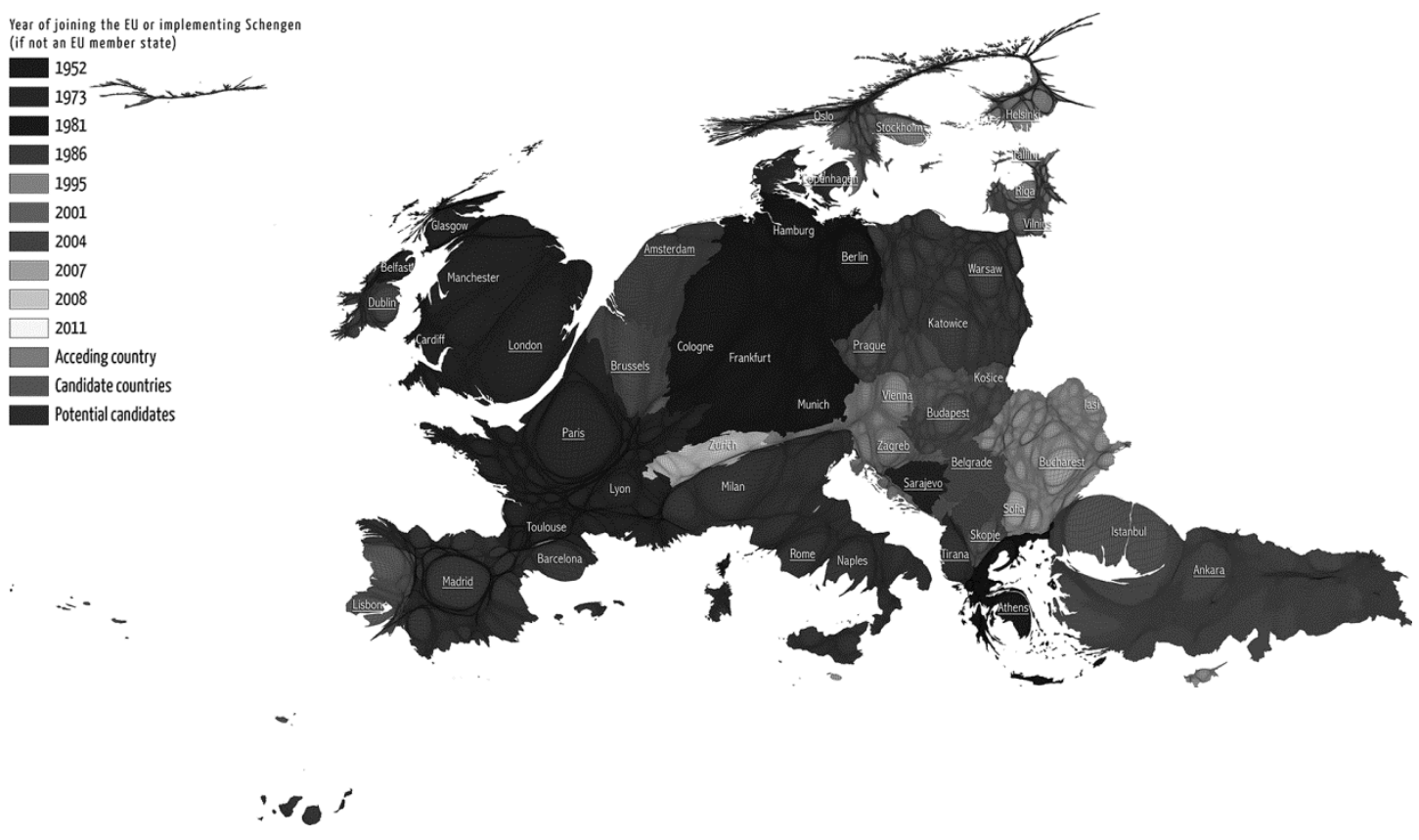

Figure 2: A gridded-population cartogram of Europe (see on-line appendix for original colour version in which the shades are far easier to distinguish)

Figure 2 has been produced as the result of the application of the method described in Figure 1 in order to redraw the spatial extent of each geographical area on the basis of fine-level spatial information about where people live rather land mass. The map highlights clearly where most people are concentrated - in many cases in cities, but also giving the more rural populations especially in Eastern Europe a fair representation. For instance, Madrid, Paris, Istanbul and London are huge, while the 
whole of Scandinavia is small. Countries and regions that are more densely populated (for example most of the UK, Italy, Poland, and Romania) are more visible on the map whereas the large rural areas in the north of the Europe appear considerably smaller. The Rhine-Ruhr metropolitan region in Western Europe, including stretching from Cologne in the west to Dortmund as its eastern edge and other urban areas that appear to be expanding towards the Netherlands, is much more prominent on this projection than it is on a conventional map.

These cartograms differ from conventional approaches to mapping socio-economic data, such as those approaches that use choropleth maps of population data which typically shade regions with boundaries defined on the basis of their area size in proportion to the measurement of a variable of interest and which make concentrations appear where they are not and tend to dissolve existing patterns. In contrast, the human cartographic approach adopted in this paper addresses such issues much more effectively and it is particularly suitable for the analysis of social and spatial inequalities as it places the focus on where most people are, and then on how they most differ from each other, offering new insights into the geographical manifestations of poverty and wealth.

\section{MAPPING AND ANALYSING REGIONAL GEOGRAPHIES OF POVERTY, AUSTERITY AND INEQUALITY IN EUROPE}

In this section we adopt the regional geovisualisation approach described above to highlight the geographical dimension of social inequalities, poverty and wealth in Europe. We first consider inequality as the degree of attractiveness of a particular area 
to the dominant form of economic activity, following Massey's (1979) definition, discussed above. In particular, we use the traditional measure of Gross Domestic Product (GDP). We use the latest data from Eurostat on GDP by NUTS2 region, with each area being compared to the EU average in order to paint the current picture of the geography of wealth and purchasing power in Europe. The map shown in Figure 3 is drawn with small areas resized in proportion of the population living within them (see Figure 2 for city labels). The total GDP per capita by region is then used to shade and classify areas. In this map it is becoming evident that some of the most affluent city regions have more in common with other wealthy regions across Europe than the rest of the country within which these regions lie and this relates to the discussion of some of the conditions that are widely accepted as pre-requisites for a successful monetary union.
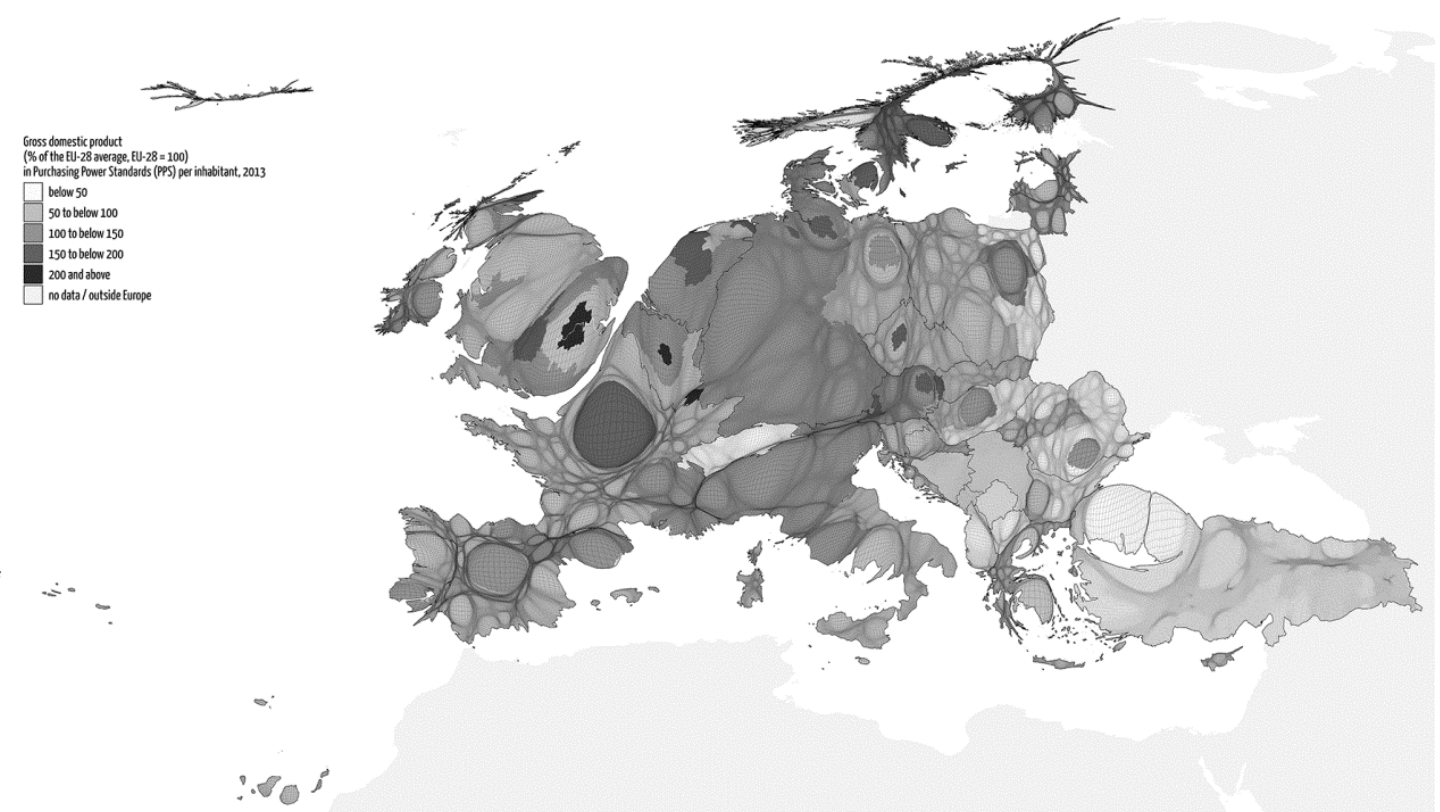

Figure 3: Gross Domestic Product (\% of the EU-28 average, EU-28 = 100) in Purchasing Power Standards (PPS) per inhabitant, 2013. Data from Eurostat. (see online appendix for colour version) 
The values mapped show GDP per capita in Purchasing Power Standards (PPS) in relation to the EU average set to equal 100. If the index of a region is higher than 100 then this region's level of GDP per head is higher than the EU average and vice versa. The cartogram reveals an East-West divide (and to some extent a NorthSouth divide) across Europe. But there are also considerable disparities within countries. It should be noted that if regional data for the western Balkan counties and Turkey had been available, then the regions within them would almost certainly have also been at the bottom of the league the cartogram reveals. It is also interesting to note the disparity in the GDP of Madrid compared to most of the rest of Spain and that of Rome and Milan at the possible expense of Naples and much of the rest of Italy. Paris takes even more in comparison to almost all of the rest of France. However, it is the city region of London which has by far the highest GDP per capita (index 325 compared to EU28 = 100), followed by the city regions of Luxembourg (index of 257.7), Brussels (207.2), Hamburg (207.2) and Groningen (187.2). Looking at the least affluent areas in Europe, the city region of Severozapanden in northwest Bulgaria is the poorest in Europe (with an index of 30.1) together with most other regions in the country as well as in neighbouring Romania but also in Hungary and Poland.

It is also interesting to consider these patterns in relation to our earlier discussion regarding the need to meet the criteria for a successful monetary union and the arguments that failure to do so has been a contributing factor to the 2008 crisis. For instance, London has much more in common with the other very affluent (in terms of GDP) regions highlighted above, at least from an economic and productive similarity point of view. In addition, there are high rates of geographical mobility to these regions (not just of capital but also labour). On the other hand, it is interesting to 
note that regions in northern England and Scotland are more similar in terms of GDP with regions elsewhere in Europe compared to regions within the British Sterling monetary area they belong to in the South and South-East England. The regions of South Yorkshire (index 75.9 compared to EU28 = 100), Lincolnshire (index 75.7) and Cornwall and the Isles of Scilly (70.3) are more similar to the Southern Aegean island region of Greece (index 76.2), the Portuguese Madeiras islands (74.3) and the region of Lower Silesia (75.5) in south-west Poland, rather than the British south.

It should also be noted that some of the city regions highlighted above are linked through extensive commuting networks to a larger hinterland and that the inhabitants of that hinterland contribute to the GDP produced within the cities but are usually not counted in indicators per head, such as the one mapped here. Therefore, some of these regions (and perhaps most notably London, Brussels and Hamburg) may emerge as having an exaggeratedly high GDP per inhabitant simply because so many of their workers reside outside their boundaries. In order to obtain a more accurate picture of the income and living conditions of the people actually residing within the regional borders it is more appropriate to draw on indicators pertaining to the second type of Massey's definition of inequality, that of social well-being. An example of such an indicator is shown in Figure 4, which depicts the regional distribution of Europeans who are in poverty or are considered to be at risk of poverty. These are persons who live in a household with an equivalised (to control for household size) disposable income below the risk-of-poverty threshold, set at $60 \%$ of the national median equivalised disposable income (after social transfers).

The cartogram shown in Figure 4 is drawn with small areas resized in proportion of the population living within them and then shaded to show the numbers of people across European regions who live on an income that is less than that of the 
$60 \%$ of the national median income. High rates of poverty have been a persistent stark feature of the most affluent cities within the most economically unequal and regions of Europe. The most characteristic example is the city region of London which has a very high poverty rate $(32 \%)$ and at the same time, as seen in Figure 3, has by far the highest level of GDP per capita in Europe. Similarly, the city region of Brussels which has the third highest GDP per capita in Europe also has a very high poverty rate (33.7\%). Nevertheless, it is also interesting to note that other large European capitals such as Berlin, Paris, Madrid and Rome do not tolerate such extreme poverty.

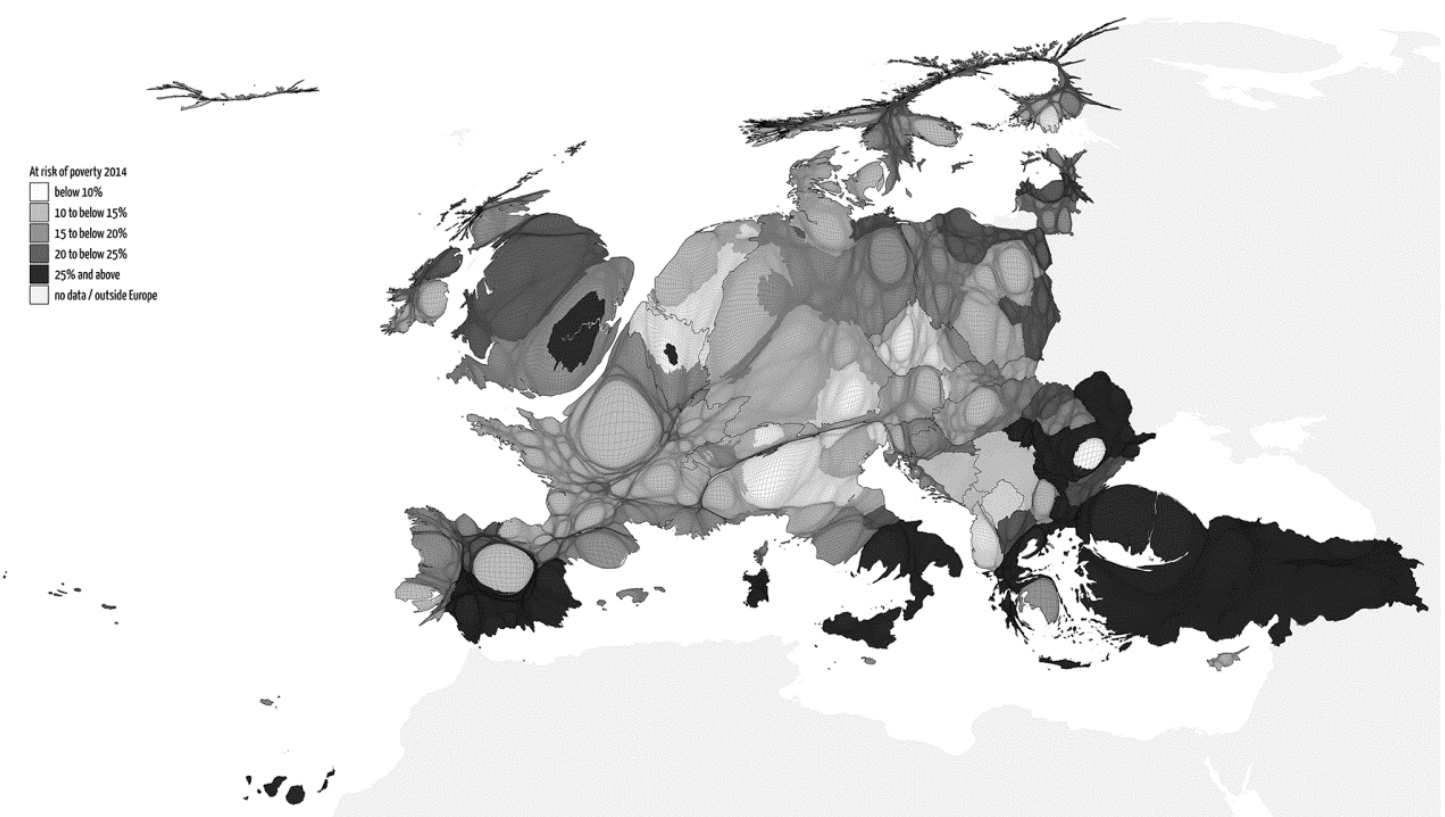

Figure 4: At risk of poverty, 2014 (data from Eurostat) (see on-line appendix for colour version)

However, the severe economic crisis and austerity measures have led in many cases to an enhancement of poverty in Southern and Eastern Europe. There are 40 European regions that have extremely high poverty rates (of over $25 \%$ of their populations being poor) and all these are shaded in deep blue, as well as Turkey, which is mapped as a single region here due to the lack of data for smaller areas 
within Turkey. These 40 regions are mostly in Southern and Eastern Europe and in particular in Bulgaria, Greece (all Greek regions except the capital city region of Athens), Southern Italy and Spain (including the Canary Islands).

Figure A.4 in the accompanying online appendix shows the regional distribution of another relevant variable: the average annual net household disposable income (for a detailed definition, see online appendix). Most of the regions with very high average household income are found in Germany, especially in the west of Germany, and in France, Austria, northern Italy and a small slither of the south of England and now the very centre of London. On the other hand, the regions in the lowest household income category are all in Eastern Europe and in particular in Bulgaria, the Czech Republic, Estonia, Hungary, Latvia, Poland, Romania and Slovakia. It should be noted that, as it was the case with the regional maps of GDP, there were no data for regions of Turkey and Western Balkan countries that have some of the poorest regions in Europe. It is even more important to note that these are arithmetic mean averages. Most households will be living on less than these amounts in all regions (as shown in the following maps) and very many where income inequalities are the highest in Europe, such as in Southern England. Most people are not well off in richer regions.

Amongst the key determinants of poverty are low-pay, social exclusion and unemployment. Following the economic crisis of 2008, some countries and regions of Europe have been sinking into a protracted period of mass unemployment reminiscent of pre-world-war-two. The unemployment rate in the EU rose from $7 \%$ in 2008 to $11 \%$ in 2013 , by when there was an estimated total of 32 million unemployed people. Of these, an estimated 7 million were aged 15-24. The overall youth unemployment rate in the entire EU by 2013 was $25.8 \%$ with very little signs of this improving 
recently. However, there are huge variations between countries and regions as well as within regions and cities, with the highest unemployment rates mostly found in austerity-stricken Greece, Italy and Spain. The next two cartograms give an impression of these geographical disparities in work and in having no work, showing how much a few areas have suffered while others have seen very little rise in unemployment at all since 2008 .

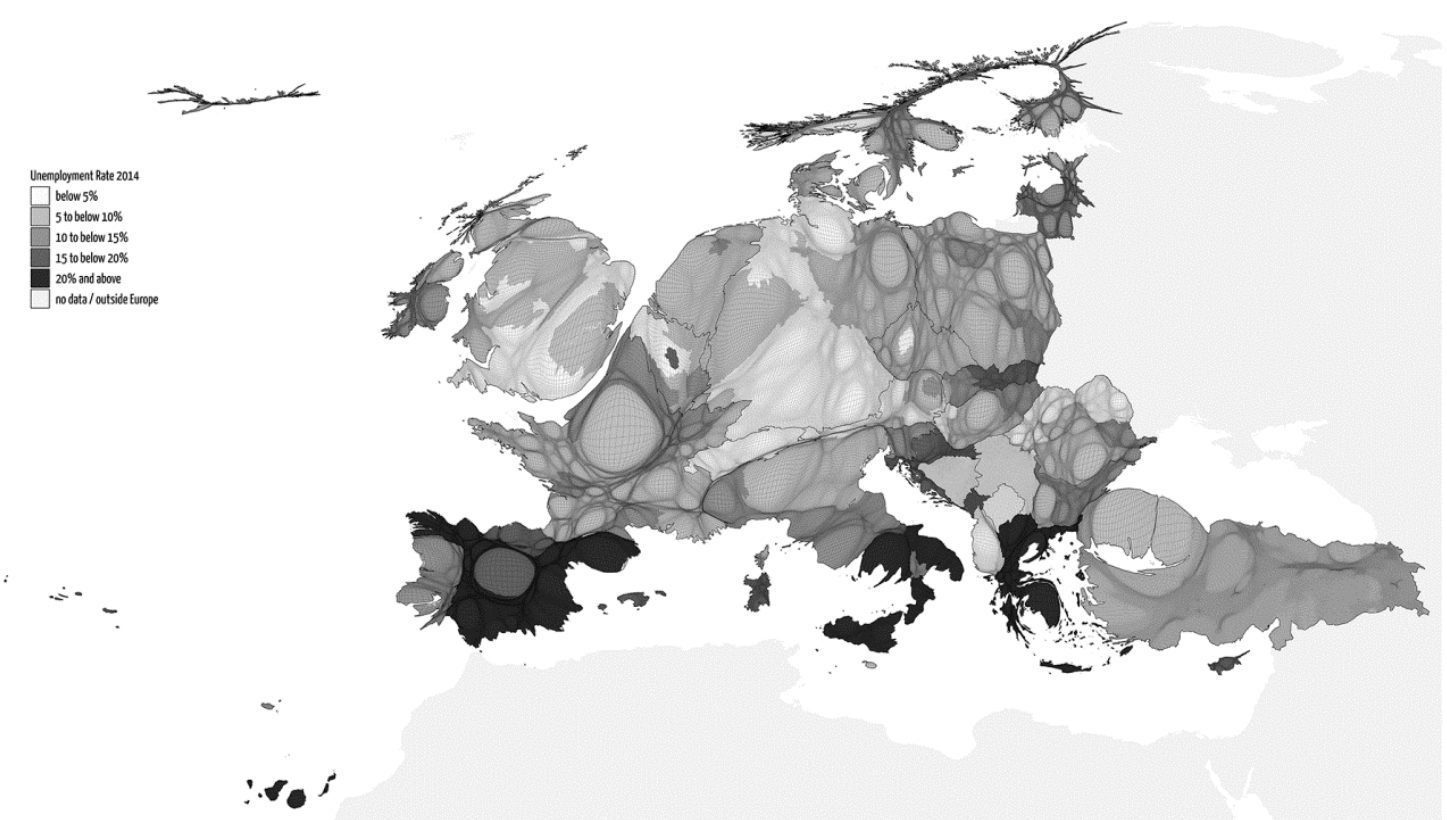

Figure 5: Unemployment rate by region, 2014 (data from Eurostat) (see on-line appendix for colour version)

Figure 5 depicts the geographical distribution of unemployment rates for the most recent year for which data were available at regional level. The highest unemployment rates are mostly found in the austerity-stricken regions of Greece, Italy and Spain. The Spanish region of Andalusia has the highest unemployment rate in Europe (34.8\%). In addition, there were a total of 30 regions with unemployment rates of over $20 \%$. These include all of the 13 Greek regions as well as 13 regions in Spain and four in Italy. In contrast, the lowest observed regional unemployment rate in 
Europe in 2014 was $2.5 \%$ and is observed in two regions: the capital city region of Prague in the Czech Republic and the German region of Upper Bavaria (which includes the city of Munich).

Overall, the regions with very low unemployment rates in that year (less than 5\%) were mostly found in Central and Northern Europe and in particular, Germany, Austria, Switzerland, the Scandinavian countries, but also in Romania and the United Kingdom. It is also worth noting that unemployment is now often highest in areas where more women have moved away compared with the number of men who have emigrated from those areas. The patterns in Figure 5 also suggest that unemployment rates are lower in major cities than in the areas around them, as people are drawn into the cities for work and cannot afford to live there if they do not have work in most, but not all, cases. Rates are also a little higher in places where benefits are less punitive and where sanctions are not applied to force people to take work they would rather not do because it is often dangerous, dirty, undignified and very lowly paid.

The next and final cartogram considers change in unemployment rates during a period of severe recession and austerity affecting many parts of Europe. The cartogram shown in Figure 6 shows the geographical distribution of changes in unemployment rates across European regions between 2008-2014. The regions with the highest increases (over 10\%) are all in the south of Europe, in countries very badly hit by the economic crisis. In particular, these regions include most of Spain, all of Greece and Cyprus, the region of Calabria in Southern Italy and the Portuguese island region of the Azores. On the other hand, there have been 83 regions across Europe where the unemployment rate in 2014 was lower than that of 2008. Most of these regions are in Germany and Turkey, but also in Eastern Europe and the United 
Kingdom. Nevertheless, as noted above, unemployment rates fell in many parts of the UK because in recent years up to a million people a year have been 'sanctioned' if they do not take any job and so many take what are called zero-hours jobs (which can involve no work in particular weeks) or pretend they are self-employed while receiving hand-outs from relatives.

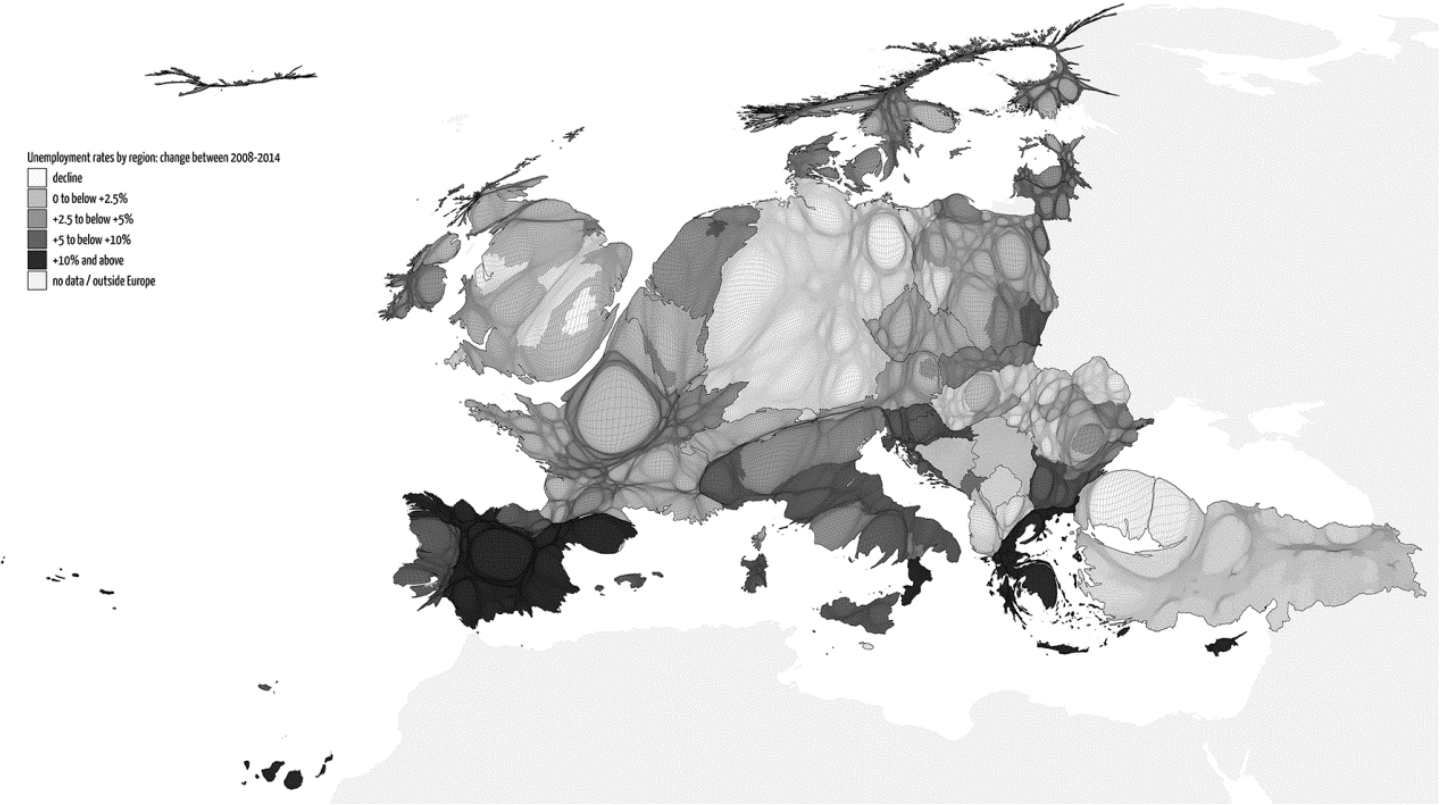

Figure 6: Unemployment rates by region: change between 2008-2014 (data from Eurostat). (see on-line appendix for colour version)

Figures A.7 and A.8 in the online appendix show snapshots of changes related to the earlier stages of crisis and austerity. In particular, they show how the changes in household incomes and the GDP index respectively, following the beginning of the financial crisis and recession in Europe in 2007-08 through to 2011 which was the most recent consistent regional data at the time of writing this article. The largest falls in household disposable income (Figure A.7) are seen in Greece. The highest decline in income recorded across the whole of Europe during these four years was in 
the Athens capital city region of Attiki. However very considerable falls in average income were also experienced in some regions of Italy, Spain and the United Kingdom (including London where bankers' bonuses were cut for a few years). Conversely, most of the regions where average household incomes increased are generally found in Central and Eastern Europe and this picture may be consistent, to some extent, with the conclusions of RAE (2011) that were briefly discussed above. The map of regional GDP (Figure A.8) change also reveals similar patterns, showing that a very large number of the regions experiencing a decrease in GDP per inhabitant were in the south of Europe, but they can also be seen in the periphery of some central and northern European countries. In great contrast to those areas, there were 22 regions experiencing an increase of more than $2 \%$ in their GDP per capita. Of these, 13 are in Poland, seven in Germany (mostly in the east) and the remaining two are the French island region of Corsica and the Slovakian capital city region of Bratislava.

It is also worth noting that many of the regions that are most heavily affected by the recent recession and austerity also have the highest rates of highly qualified human resources and University graduates (especially in Greece and Spain - see Figure A.9 in the online appendix). Futhermore is also worth noting that the highly qualified professionals in the regions hit the hardest by the recession and massive government cuts have been migrating over the past five years to areas with lower unemployment (BARNATO, 2012), mostly into the north and into countries like Germany. It can be argued that such movements of population help some regions and countries to overcome their skill shortages. These developments are also very relevant to the 'successful monetary union' pre-requisite of 'high rates of geographical mobility, not only for capital but also for labour' that was briefly discussed above. 
However, recent population movements can also be seen as a brain-drain for the originating regions (ANASTASIADOU, 2016; LABRIANIDIS and VogIATZIS, 2013) with further negative economic and social implications. In any case, it is very important to point out that the cost of educating highly qualified professionals was typically not covered by the receiving country, but rather by the tax-payers of those sending countries, like Greece, Italy, Spain and Portugal, which made huge investments in their higher education systems in past decades. The same argument can also be made over the initial costs of education of many of the migrants from Syria that have arrived in such large numbers in Europe in recent years. In particular, the investments in higher education made by these countries in the past decades (and which have contributed to their high overall levels of government debt) are now benefiting the EU as a whole via the migration of highly skilled groups of individuals (BALLAS, 2014).

\section{CONCLUSIONS AND DIRECTIONS FOR FURTHER RESEARCH}

This paper has offered a human cartographic approach to conceptualising Europe as one place and of mapping its regional geography to that end, with a particular focus on themes that are timely and relevant to current debates about the need for panEuropean solidarity as a pre-requisite for pan-European policy responses to offset and reverse the impact of austerity in regions that suffered the most.

The maps presented here highlight very important and sometimes extreme social and spatial disparities, including revealing many economic inequalities that call strongly for socially and environmentally sustainable action. They also reveal that the real 
differences in the quality of life and the types of challenges and problems faced by Europe's populations are not found across national borders but between regions within countries, between villages and cities or between rich and poor quarters of a town. And the rich quarters of Europe are all more similar to each other than to the poorer areas that are nearer to them.

There have been considerable efforts expended over the past couple of decades aimed at putting in place and implementing cohesion policies at the European level and at correcting imbalances and ameliorating geographical inequalities. Examples of such policies include the European Social Fund, the European Regional Development Fund and the Cohesion Fund. The more recent initiative is the European Commission 'Investment Plan for Europe' aimed at mobilising investment of at least $€ 315$ billion and kick-starting the real economy (European Commission, 2016) and which has been described as a new Marshall plan for the EU (Bell, 2015). The human cartographic approach presented in this paper can be used to offer insights into which regions are most in need for different types of economic support and which areas are more likely to benefit from such initiatives, providing the basis for further analysis.

Overall, the themes mapped and discussed in this paper can be used to inform debates about the role that geographers and Regional Studies researchers can play in contributing to and informing as well as shaping debates about the possible revival of the idea of full employment, better employment and social progress as a key European goal, freedom and ideal. There is a need, apart from the political and economic argument, to enhance the feelings of social cohesion and solidarity amongst the people of Europe if political progress is to be made. The work presented in this paper 
could be used to achieve this by highlighting important disparities and inequalities and, at the same time, reminding Europeans how much they have in common, how they live in one continent with great similarities across its space, and the potential for what can be achieved if there is a move away from a 'nation state mentality', thinking instead about Europe as a continent of cities and regions rather than states..

\section{References}

ANASTASIADOU, S (2016), Economic Crisis in Greece and the Consequential "Brain

Drain, in Karasavvoglou, A, Aranđelović, Z, Marinković, S, Polychronidou, P

(eds.), The First Decade of Living with the Global Crisis, Springer, pp. 113-120.

ANNONI, P, DIJKSTRA, L (2013), EU Regional Competitiveness Index 2013, European

Commission, EUR 26060. Luxembourg: Publication Office of the European Union,

http://ec.europa.eu/regional_policy/sources/docgener/studies/pdf/6th_report/rci_20

13_report_final.pdf [Accessed 17 May 2016].

BAILEY, N, TUROK, I (2000), Adjustment to Job Loss in Britain's Major Cities, Regional Studies, 34, pp. 631-653.

BALLAS, D (2014), The political economy of 'a country called Europe', speri.comment: the political economy blogSheffield Political Economy Research Institute, http://speri.dept.shef.ac.uk/2014/11/27/political-economy-a-country-called-europe/

BALLAS, D, (2016), A letter from Lesvos, speri.comment: the political economy blog, http://speri.dept.shef.ac.uk/2016/01/06/a-letter-from-lesvos/

BALLAS, D, DORLING D (2011) Human Scaled Visualisations and Society, in Nyerges, T, Couclelis, H, McMaster, R (eds.), Handbook of GIS \& Society Research, Sage, 177-201.

BALlAS, D, DORLING D, HENNIG, B (2014), The Social Atlas of Europe, Policy Press, Bristol.

BALLAS, D, DORLING D, HENNIG, B (forthcoming2017), The Human Atlas of Europe: 
a continent united in diversity, Policy Press, Bristol.

BARNATO, K (2012), Emigrating Greeks Prove the EU Is Working, CNBC, 18 June 2012, available from: http://www.cnbc.com/id/47828618

Page 24 of 44

BELL, C (2015), The European investment plan - A new Marshall plan for the EU?, The Parliament Magazine, available from:

https:/www.theparliamentmagazine.eu/articles/special-report/europeaninvestmentplan-new-marshall-plan-eu

BRAMLEY G. \& SMART G. (1996) Modelling local income distributions in Britain, Regional Studies, 30(3), 239-255

CARSTAIRS, V. (1995) Deprivation indices: their interpretation and use in relation to health, Journal of Epidemiology and Community Health, 49: 3-8

DICKEN, P (2015), Global Shift: Mapping the Changing Contours of the World Economy, Sage, London

DORLING, D (1995), A New Social Atlas of Britain, John Wiley, Chichester, Sussex

DORLING, D (2015), Injustice: Why social inequality still persists, Policy Press, Bristol.

DORLING, D (2016), Brexit: the decision of a divided country, BMJ;354:i369

DORLING, D, FAIRBAIRN, D. (1997) Mapping: Ways of Representing the World, Longman, Harlow, Essex

DORLING, D, NEWMAN, M, BARFORD A (2008), The Atlas of the Real World, Thames and Hudson.

DORLING, D., RIGBY, J., WHEELER, B., BALLAS, D. THOMAS, B., FAHMY, E., GORDON, D., and LUPTON, R. (2007). Poverty, wealth and place in Britain, 1968 to 2005.

Bristol: Policy Press. 
DORLING, D. and THOMAS, B. (2016), People and Places: A 21st Century Atlas of the UK, Policy Press, Bristol

DOXIADIS, A.,MATSAGANIS, M. (2012), National Populism and Xenophobia in Greece. Counterpoint UK [Online], Creative Commons http://counterpoint.uk.com/wpcontent/ uploads/2013/01/507_CP_RRadical_Greece_web-1.pdf [Accessed 28 October 2016].

EUROPEAN COMMISSION (2015). Eurostat regional yearbook 2015 Eurostat statistical books. Luxemburg: Publication Office of the European Union.

http://ec.europa.eu/eurostat/documents/3217494/7018888/KS-HA-15-001-ENN.

pdf [Accessed 17 May 2016].

EUROPEAN COMMISSION (2016), Investment Plan for Europe, http://ec.europa.eu/priorities/jobs-growth-and-investment/investment-plan_en

FRIEDMAN, R., THIEL, M. (eds) (2016). European Identity and Culture: Narratives of Transnational Belonging, Routledge

FUJITA, M, VENABLES, A J, KRUGMAN, P (1999), The Spatial Economy: Cities, Regions, and International Trade, MIT Press, MA

GASTNER, M T, NEWMAN M E J (2004) Diffusion-based method for producing density equalizing maps, Proc. Natl. Acad. Sci. USA 101, 7499-7504.

HADJIMICHALIS, C (2011) Uneven geographical development and socio-spatial justice and solidarity: European regions after the 2009 financial crisis, European Urban and Regional Studies 18(3), 254-274.

HADJIMICHALIS, C, HUDSON, R (2007) Rethinking local and regional development: implications for radical political practice in Europe, European Urban and Regional Studies 14(2), 99-113.

HADJIMICHALIS, C, HUDSON, R (2014), Contemporary Crisis Across Europe and the Crisis of Regional Development Theories, Regional Studies, vol. 48, pp. 208-218. 
HALKIOPOULOU, D, VASILOPOULOU, S (2014), Scapegoating Europe? How discontent with domestic politics determined the EU vote, Open Democracy, available from:

https://www.opendemocracy.net/can-europe-make-it/daphne-halikiopoulou-sofiavasilopoulou/ scapegoating-europe-how-discontent-with-d

HALIKIOPOULOU, D., VLANDAS, T. (2016) Risks, costs and labour markets: explaining cross-national patterns of far right party success in European Parliament elections, Journal of Common Market Studies, 54 (3). pp. 636-655

HAMNETT, C. (1997), A stroke of the Chancellor's pen: the social and regional impact of the Conservative's 1988 higher rate tax cuts, Environment and Planning A, 29, 129-147

HARVEY, D (2011) Crises, geographic disruptions and the uneven development of political responses, Economic Geography 87(1), 1-22.

HENNIG, B. (2013). Rediscovering the World. Map Transformations of Human and Physical Space. Heidelberg / New York / Dordrecht / London (Springer).

HENNIG, B. D. BALLAS, D., DORLING, D. (2015): In Focus: Europe's uneven development. Political Insight 6 (3): 20-21.

HENNIG, B. D., CALZADA, I. (2015). In Focus: Regions between Recentralisation and Independence. Political Insight 6 (1): 20-21.

HUDSON R. (2007) Regions and regional uneven development forever? Some reflective comments upon theory and practice, Regional Studies 14(9), 1149-1160.

KITSON, M., MARTIN, R, TYLER, P (2011), The geographies of austerity, Cambridge Journal of Regions, Economy and Society, pp. 289-302.

KRUGMAN, P (1991) Geography and Trade, MIT Press, Cambridge, MA.

LABRIANIDIS L, VOGIATZIS, N (2013), Highly Skilled Migration: What Differentiates the 'Brains' Who Are Drained from Those Who Return in the Case of Greece, Population, Space and Place, vol. 19, pp. 472-486. 
MARTIN, R (2011) The local geographies of the financial crisis: from the housing bubble to economic recession and beyond, Journal of Economic Geography 11, $587-618$.

MARTIN, R (2001) EMU Versus the Regions? Regional Convergence and Divergence in Euroland, Journal of Economic Geography, vol. 1, pp. 51-80.

MASSEY, D B (1979) In what sense a regional problem?, Regional Studies 13, 233-243.

MASSEY, D. (1995), Spatial divisions of labour: social structures and the geography of production (2nd edition), Macmillan, London.

MCCANN, P, SHEPPARD, S (2003), The rise, fall and rise again of industrial location theory, Regional Studies, 37, pp. 649-663.

MIDELFART, K. H., OVERMAN, H, VENABLES, A (2003) Monetary union and the economic geography of Europe, Journal of Common Market Studies 41(5), 847-868.

MYRDAL, G (1957) Economic Theory and Under-developed Regions, Methuen, London.

PECK, J. (1996), Work-Place: the social regulation of labor markets, The Guilford Press, New York.

PIKE, A, RODRIGUES-POSE, A, TOMANEY J (2007) What kind of regional development and for whom?, Regional Studies 41, 1253-1269.

RAE, G (2011) On the periphery: the uneven development of the European Union and the effects of the economic crisis on Central-Eastern Europe, Global Society, 25(2), 249-266.

RITTSCHOF, K. A., STOCK, W. A., KULHAVY, R. W., VERDI, M. P., \& JOHNSON, J. T. (1996). Learning from cartograms: The effects of region familiarity. Journal of Geography, 95(2), 50-58.

ROSE, M (2016), EU support surges in big European countries after Brexit vote, Reuters, 20 July 2016, available from: http://uk.reuters.com/article/uk-britain-eupoll-idUKKCN1002A0 
SMITH, A (2013) Europe and an inter-dependent world: uneven geo-economic and geo-political developments, European Urban and Regional Studies 20(1), 3-31.

SMITH, T, NOBLE, M, NOBLE, S, WRIGHT, G, MCLENNAN, D, PLUNKETT, E (2015) The English Indices of Deprivation 2015: Research Report, Department for Communities and Local Government, available from: https://www.gov.uk/government/publications/english-indices-of-deprivation2015-research-report

STONE, J (2016), March for Europe: Thousands take to streets in cities across Britain in support of EU membership, The Independent, 3 September 2016, available from: http://www.independent.co.uk/news/uk/politics/march-for-europe-euprotestlondon-edinburgh-birmingham-oxford-cambridge-september-saturdaya 7224186. html

SZEGÖ, J. (1987), Human cartography: Mapping the world of man. Stockholm: Swedish Council for Building Research.

THE CHURCILL SOCIETY (1946), Mr Winston Churchill speaking in Zurich 19 September 1946, available from: http://www.churchill-society-london.org.uk/astonish.html TOWNSEND, P. (1979) Poverty in the United Kingdom: a survey of household resources and standards of living, Penguin Books and Allen Lane, London.

TOWNSEND, P (1987) 'Deprivation', Journal of Social Policy, 16, 125-46.

TURNER, A. J. (2006). Introduction to Neogeography. Sebastopol: O’Reilly Media.

TOBLER, W. R. (2004). Thirty-five years of computer cartograms. Annals of the Association of American Geographers, 94(1), 58-73.

ZONDEROP, Y. (2012). The Roots of Contemporary Populism in the Netherlands. Counterpoint UK [Online], Creative Commons http://counterpoint.uk.com/wpcontent/ uploads/2013/01/507_CP_RRadical_DutchEnglish_web.pdf [Accessed28 October 2016]. 


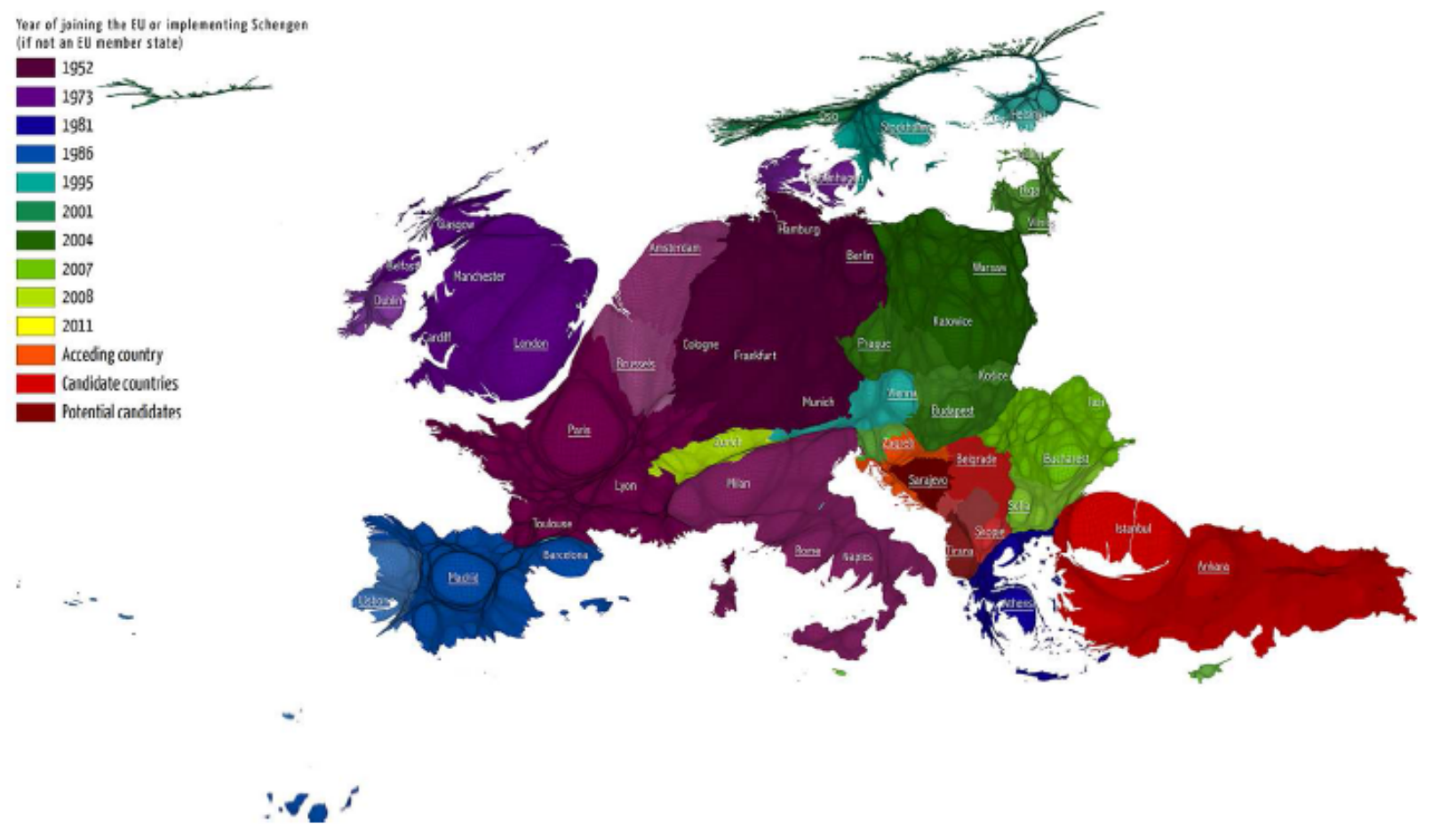

Online Appendix - Figure A.1: A gridded-population cartogram of Europe Figure A.1
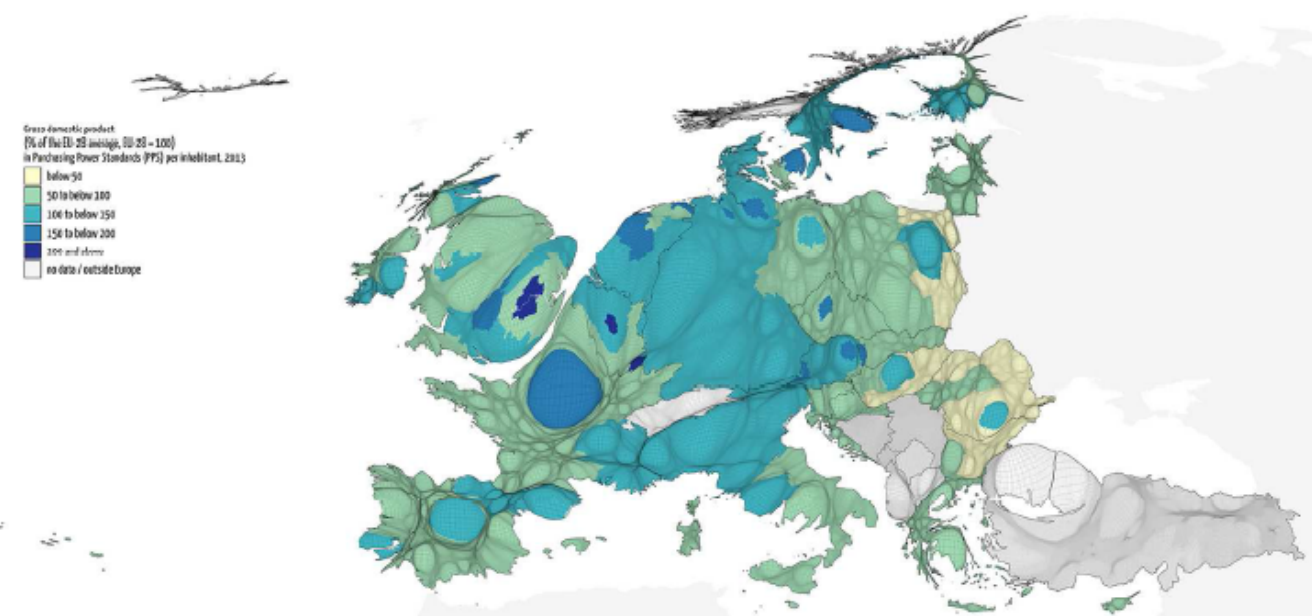

$\therefore$. 8

Online Appendix - Figure A.2: Gross domestic product (\% of the EU-28 average, EU-28 $=100$ ) in Purchasing Power Standards (PPS) per inhabitant in NUTS2 regions, 2013. Data from Eurostat. Figure A.2

$300 \times 168 \mathrm{~mm}(150 \times 150 \mathrm{DPI})$ 


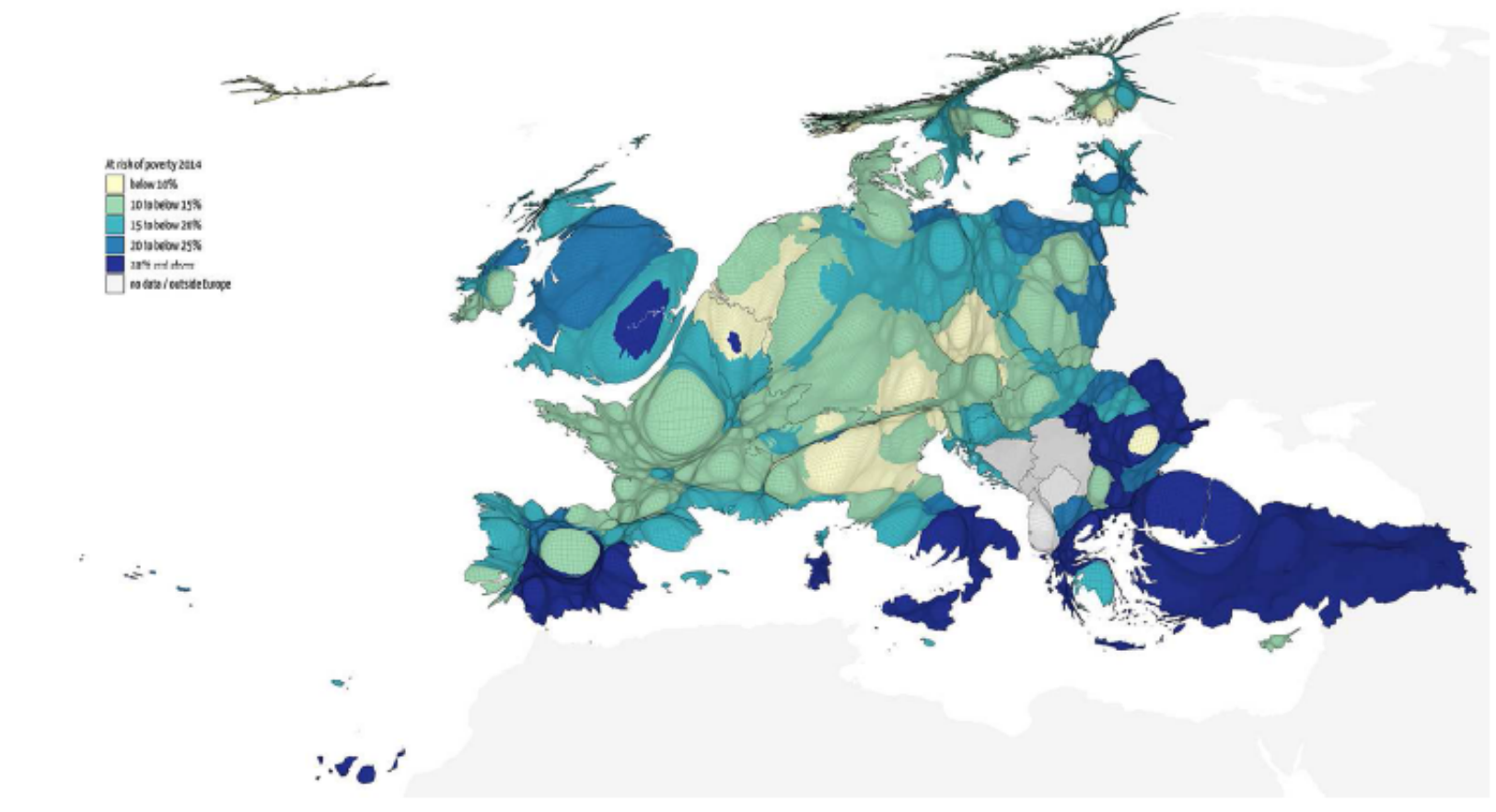

Online Appendix - Figure A.3: At risk of poverty in NUTS2 regions, 2014 (data from Eurostat) Figure A.3 $300 \times 168 \mathrm{~mm}(150 \times 150 \mathrm{DPI})$

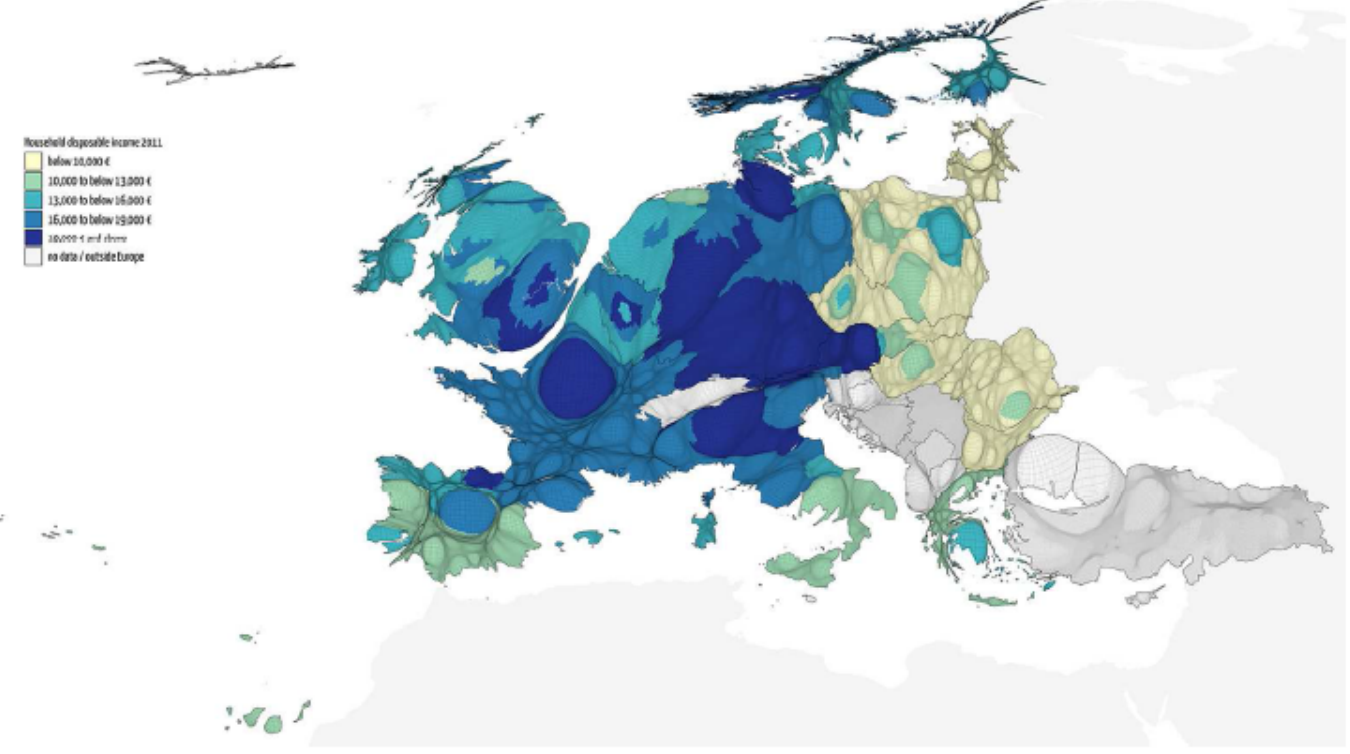

Online Appendix - Figure A.4: Household disposable income in NUTS2 regions 2011. This total income aft tax from all sources, including paid employment, property rental income, as well as welfare benefits in cas but it does not include social transfers that are made in kind rather than cash such as the provision of universal health care or free education, whether these are provided by the state or non-profit institutions (data from Eurostat)

Figure A.4

$300 \times 168 \mathrm{~mm}(150 \times 150 \mathrm{DPI})$ 


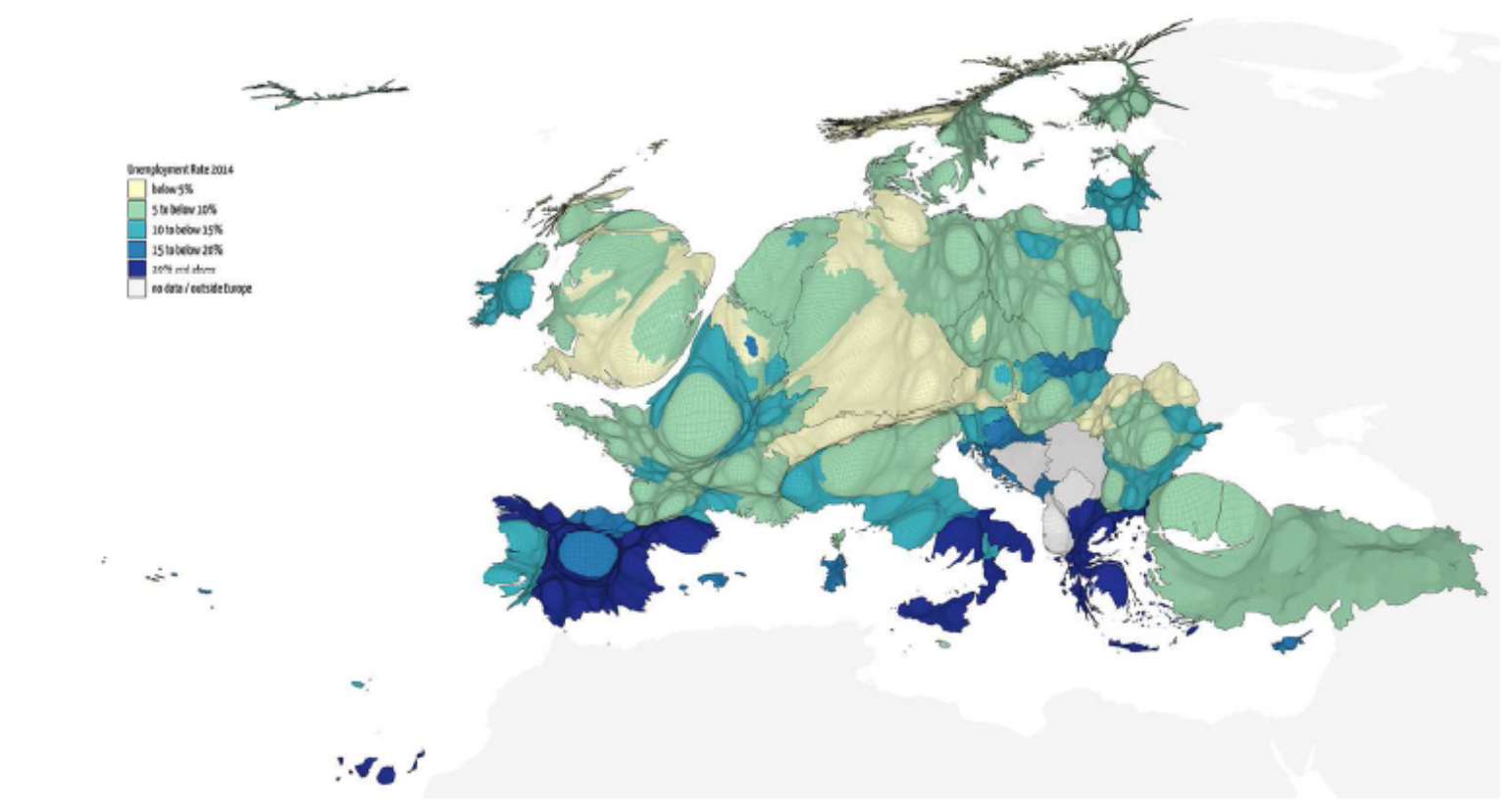

Online Appendix - Figure A.5: Unemployment rate by NUTS2 region, 2014 (data from Eurostat) Figure A.5 $300 \times 168 \mathrm{~mm}(150 \times 150 \mathrm{DPI})$

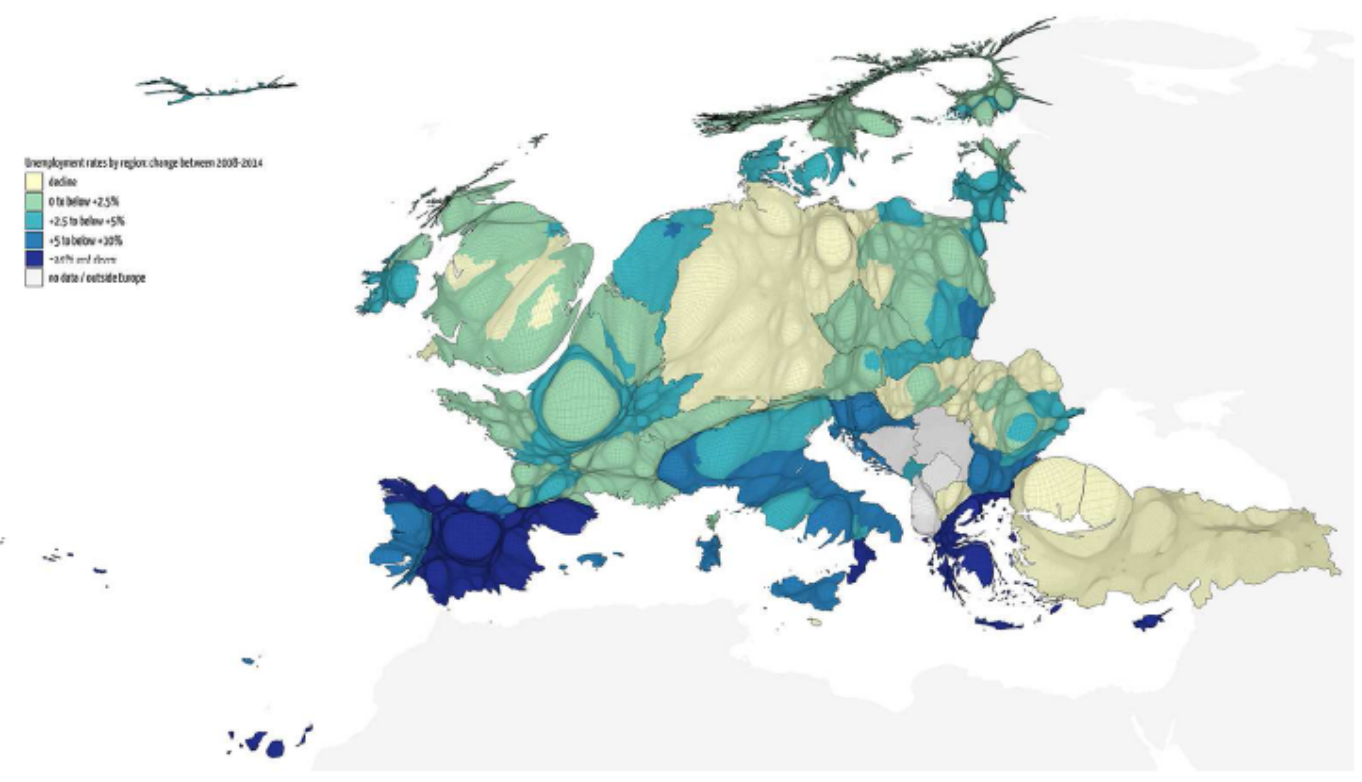

Online Appendix - Figure A.6: Unemployment rates by NUTS2 region: change between 2007-2014 (dat from Eurostat).

Figure A.6

$300 \times 168 \mathrm{~mm}(150 \times 150 \mathrm{DPI})$ 


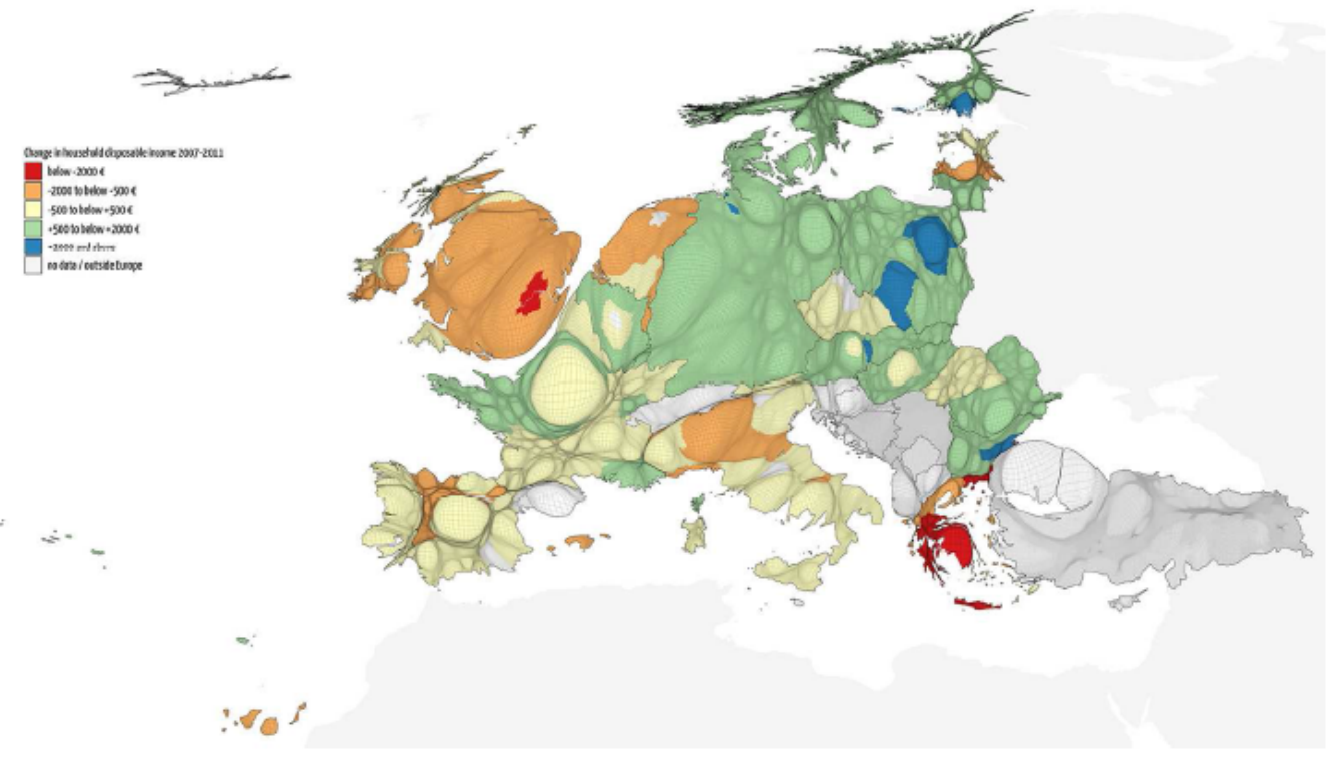

Online Appendix - Figure A.7: Change in household disposable income in NUTS2 regions, 2007-2011. Fiqure A.7 $300 \times 168 \mathrm{~mm}(150 \times 150$ DPI $)$

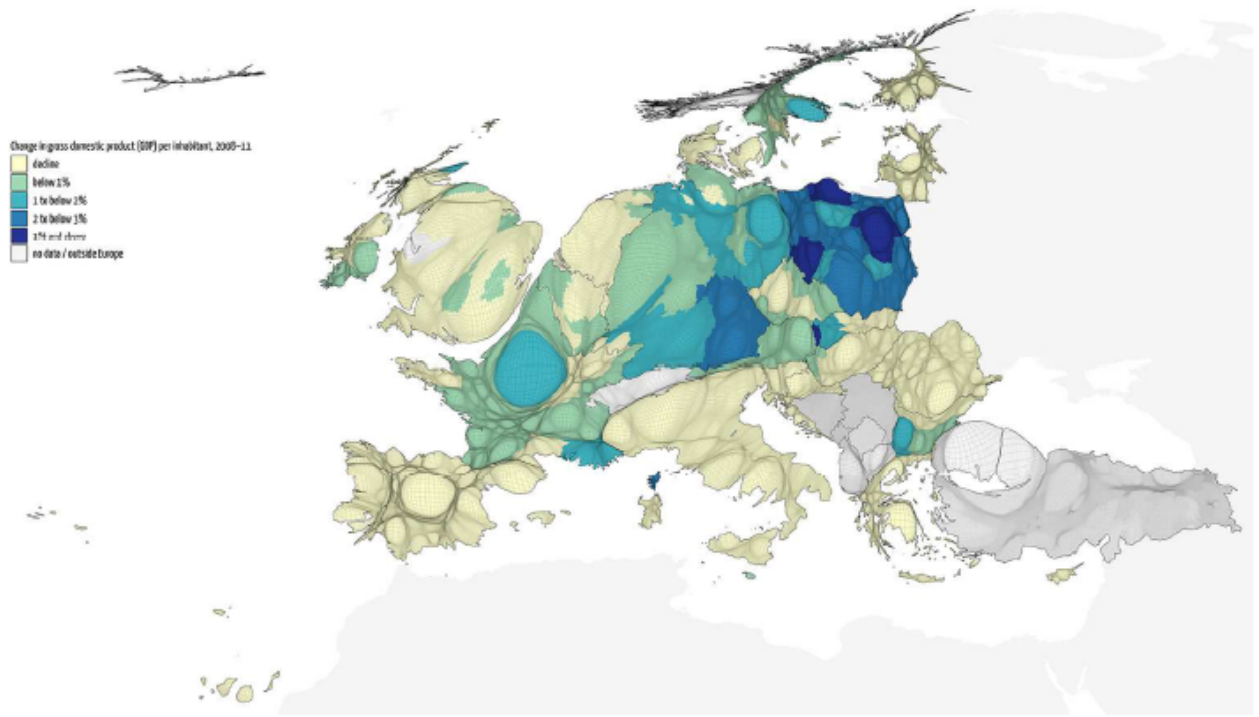

Online Appendix - Figure A.8: Change in gross domestic product (GDP) per inhabitant in NUTS2 regions, 2008-11

Fiqure A.8

$300 \times 168 \mathrm{~mm}(150 \times 150 \mathrm{DPI})$ 


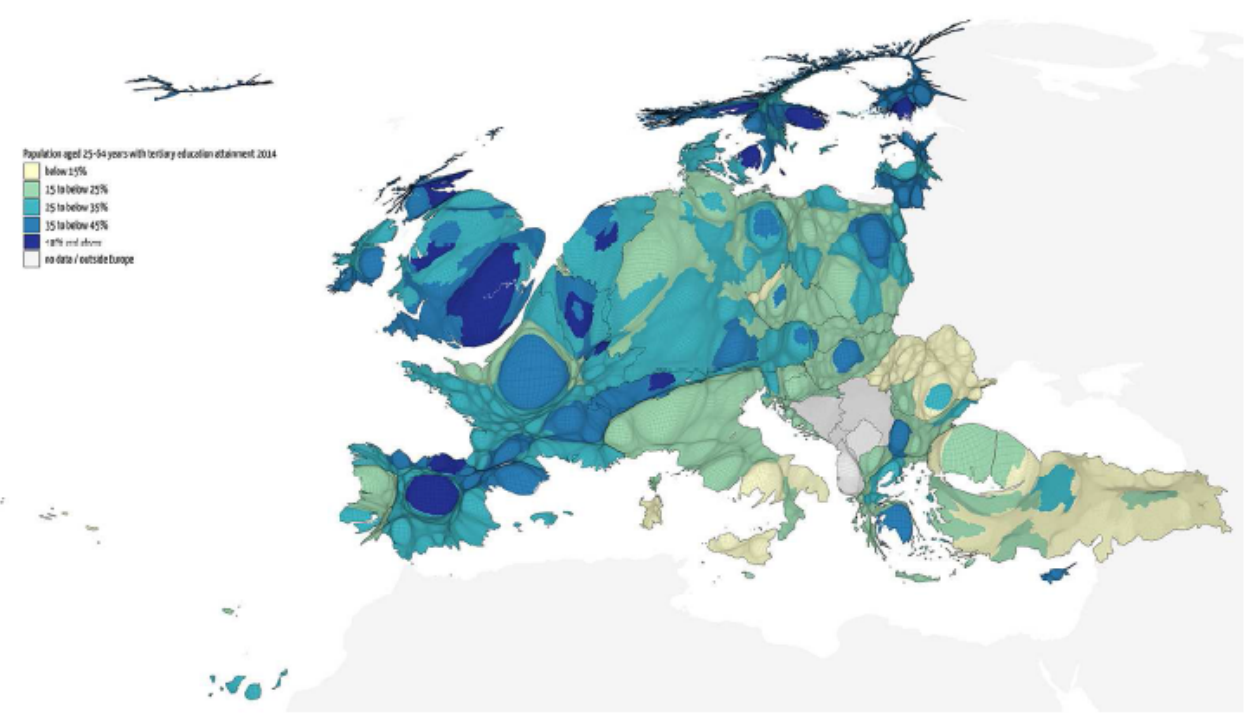

Online Appendix - Figure A.9 Population aged 25-64 years with tertiary education attainment in NUTS2 regions, 2014 Figure A.9

$300 \times 168 \mathrm{~mm}(150 \times 150$ DPI) 